\title{
ROLE OF GROWTH AT LOMBOK INTERNATIONAL AIRPORT
}

\author{
Diva Raissa Meidyana ${ }^{1}$, Siwi Novanti², Iqbal Firdaus ${ }^{3}$ \\ 1. STMT Trisakti 2. STMT Trisakti 3. STMT Trisakti \\ $\triangle$ corresponding author: siwinovanti@gmail.com
}

\begin{abstract}
Lombok has a potential to be world top tourist destination. The appearance of new Lombok airport replacing the old Mataram Airport has change Lombok to be more attractive for airlines to bring tourist to Lombok. Researchers interested to explore role of Lombok International Airport (LIA) to increase number of passengers and airlines to connect Lombok to the world. Researcher uses qualitative method and SWOT to analyze the problem.

Keywords: Air Transportation; Tourism; Airport; Lombok; Passengers; SWOT
\end{abstract}

\section{Introduction}

Airport play an important role in increasing tourists. If the airport has a small capacity, they can't accomodate a lot of passengers, and it's affect to increasing tourist. So, that's why Indonesia's government establish a development facility of transportation. This sector is a supporter of economy development and outside the country. In general, West Nusa Tenggara still requires the development of more adequate means of communications in order to achieve optimal public services and to open access to remote areas so as not to be isolated. Today, the Indonesian tourism industry is being paid serious attention by the government. The government has been seriously and fast developing various infrastructures such as airport, terminal, toll road (highway), and so on. The infrastructure development is also intended for developing the Indonesian tourism industry. (Simarmata \& Keke, 2017)

Each of the larger Indonesian islands have at least one International Airport. The biggest airport in Indonesia, Soekarno-Hatta International Airport, is located in Tangerang Regency, Banten. There are five more International Airports on Java, such as Adisumarmo International Airport in Solo, Central Java, Juanda International Airport in Surabaya, East Java, Achmad Yani International Airport in Semarang, Central Java, Husein Sastranegara International Airport in Bandung, West Java and Adisucipto 
International Airport in Yogyakarta. On Kalimantan, there is one International Airport and there are two on Sumatra such as Minangkabau International Airport in Padang, West Sumatra. Bali, which is part of the Nusa Tenggara Islands, has the Ngurah Rai International Airport, Selaparang Airport located on the west coast of Lombok was closed to flight operations on 30 September 2011. The new Lombok International Airport opened on 1 October 2011. Selaparang Airport will either be redeveloped or may possibly be retained for development as Indonesia's first General Aviation hub airport. Sam Ratulangi International Airport, also known as Manado International Airport, is located in North Sulawesi, 13 kilometres northeast of Manado. The airport is named after the Minahasan educator and independence hero Sam Ratulangi. The Manado airport is also a hub to remote areas of Eastern Indonesia, including Halmahera with both Kao airport as well as Galela, Ambon, Tidore, and Irian Jaya or West Papua. There are also direct flights to Manado International Airport from Singapore daily with Silk Air a wholly owned subsidiary of Singapore Airlines. There are three major tourists international airports arrivals, i.e. Ngurah Rai International Airport with 2.54 million, Soekarno-Hatta Airport with 1.82 million and Hang Nadim Airport, also known as Hang Nadim International Airport, in Batam, Riau Islands with 1.007 million from 7.002 million international tourists recorded as arriving in Indonesia during 2010. (Ricardianto, Djajaputra, \& Martono, 2017)

Lombok is an island in West Nusa Tenggara province, Indonesia. It forms part of the chain of the Lesser Sunda Islands, with the Lombok Strait separating it from Bali to the west and the Alas Strait between it and Sumbawa to the east. It is roughly circular, with a "tail" (Sekotong Peninsula) to the southwest, about 70 kilometres (43 miles) across and a total area of about 4,514 square kilometres (1,743 square miles). The provincial capital and largest city on the island is Mataram. It is somewhat similar in size and density with neighboring Bali and shares some cultural heritage, but is administratively part of Nusa Tenggara Barat along with sparsely populated Sumbawa. It is surrounded by a number of smaller 
islands locally called Gili. ("Lombok Demography. MarlionLLC. 2017," n.d.)

Lombok International Airport was established to support Lombok tourism. Every year, the tourists visiting Lombok increasing. On 2016, the government decided to improving the airport. At first, the airport has a low capacity that makes not many airlines can put their wings in Lombok, but then the government increasing the capacity and the runway of the airport so that the big aircraft can have a direct flight to Lombok. Looking at the increasing number of tourists and the airlines, the economic of Lombok's people also growth, the hotels in Lombok increased.

\section{Method}

This journal using SWOT analysis method. We also discussed about the total tourist that come to Lombok, airlines that opening a direct route to Lombok International Airport, the impact to the economic growth of Lombok, and Lombok tourism.

\section{Discussion and Result}

Lombok is the place that has many tourist attractions, it's top world tourist destination, besides the location of Lombok that is located near Bali, it also internationally recognized since the airport changed its name from Bandara International Airport to Lombok International Airport (LIA). Since 2016, Lombok tourism has increased and brings benefits to many aspects. First, the total passengers and the total tourists come to Lombok. The total of passenger that is come from domestic flight, the increasing of passenger reach $14.49 \%$ from the previous month, it is 169,549 people on this may. The same thing happen in total of passenger that is departed from Lombok International Airport (LIA), it reached $21.50 \%$ or 158,755 people. It also happen in international arrival terminal, the total of passenger that is come or entering Lombok reach 16,586 people, increasing $31.82 \%$ from the previous month. The increasing of international passenger also happen in 
the departure terminal, it reached $40.41 \%$ ("Dinas Kebudayaan \& Pariwisata NTB.," n.d.)

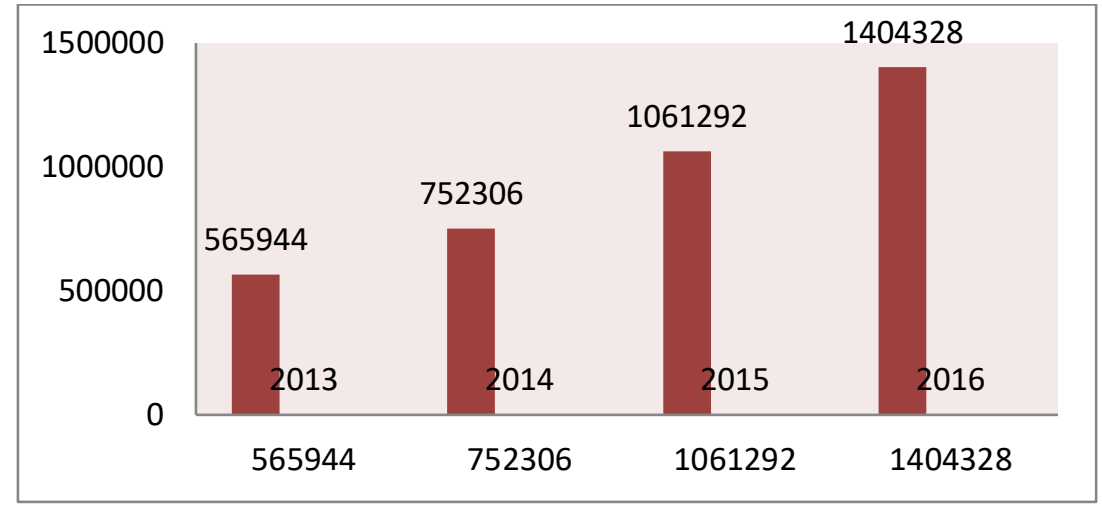

Figure 1.

Foreign Tourism to Lombok

Sources: Dinas Kebudayaan \& Pariwisata (2013-2016)

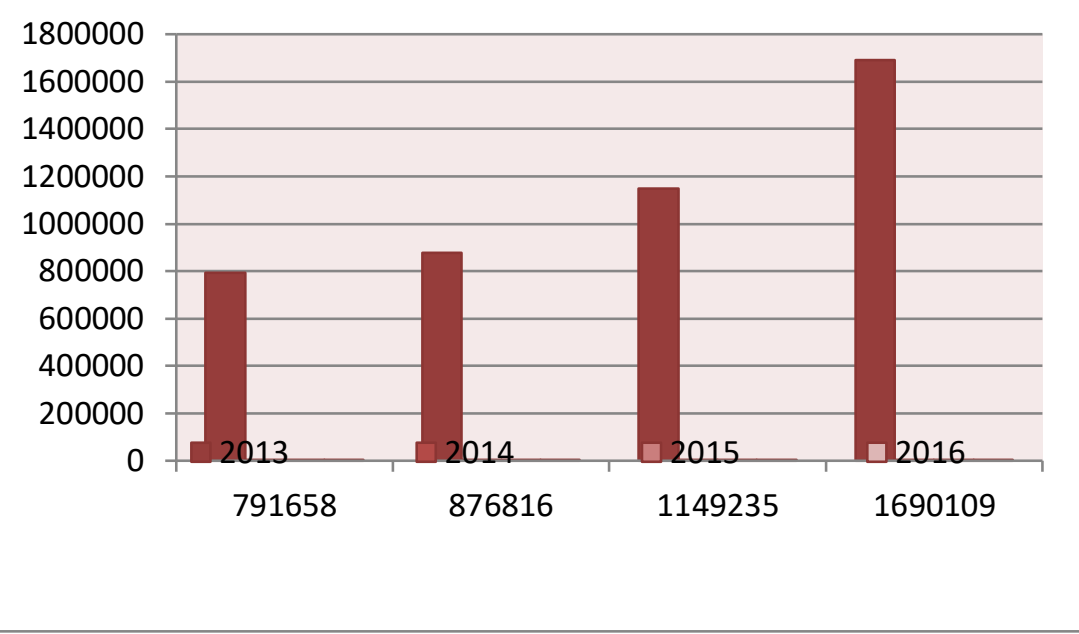

Figure 2.

Domestic Tourist to Lombok

Sources: Dinas Kebudayaan \& Pariwisata. (2013-2016).

The increase also occurred in total tourists who come to Lombok. On 2013, the total tourists that come to Lombok reached 1,357,602 people. On 2014, the total tourists increasing and reached 1,269,122, and on 2015 the tourists kept increasing until reached 2,210,527. On 2016, total tourist reached 3,094,437 people and still increasing until now. 
Table 1.

Total of Domestic and Foreign Tourist visited Lombok

\begin{tabular}{|l|l|}
\hline \multicolumn{2}{|c|}{$\begin{array}{c}\text { Total of Domestic and Foreign Tourist visited Lombok } \\
(2013-2016)\end{array}$} \\
\hline Year(s) & Total \\
\hline 2013 & 1357602 \\
& \\
\hline 2014 & 1629122 \\
\hline 2015 & 2210527 \\
\hline $2016 \quad$ Sources: Dinas Kepariwisataan \& Kebudayaan (2013-2016) \\
\hline
\end{tabular}

Article 1 (14) of Civil Aviation Act of 2009 stipulates that air transportation is any activity using an aircraft for transporting passengers, cargo, and/or post for one route or more from one airport to another airport or several airports. In relation to services, air transportation consists of full services, medium services and no-frill services. With regard to air services, the meaning of air services can be found in Article 96(b) of Chicago Convention in 1944. It provides air service means from any scheduled air service performed by aircraft for the public transportation of passengers, mail and cargo (Martono \& Marina, n.d.).

To improve services, LIA can also be used as a collecting airport so that many aircraft can enter LIA. The Collecting Airport (HUB), is an airport with a wide range of services from various airports serving large numbers of passengers and / or cargo and affecting national economic development or various provinces. The collector airport with the primary service scale is the airport as one of the supporting facilities of the National Center of Activities (PKN) service serving passengers with an amount greater than or equal to 5,000,000 (five million) persons per year; collecting airport with a secondary service scale that is the airport as one of the supporting facilities of the National Center of Activities (PKN) service serving passengers with an amount greater than or equal to 1,000,000 (one million) and less than 5,000,000 (five million ) persons per year; collecting airports with tertiary service scale ie the airport as one of the supporting infrastructure of the National Activity Center $(\mathrm{PKN})$ and the nearest 
Regional Activity Center (PKW) serving passengers with an amount greater than or equal to 500,000 (five hundred thousand) and smaller from 1,000,000 (one million) people per year. (Rafi \& Rifni, n.d.)

Lombok Airport became one of the airports within the authority of PT Angkasa Pura I (Persero) which has a considerable growth of passengers. This is because Lombok has become one of the favorite destinations for a vacation. To improve services, Angkasa Pura I continue to undertake various developments at the airport. One of the developments is to offer airline slots to foreign airlines. Based on data Lombok I International Airport, from 15 June to 3 July 2017, the number of aircraft movements was moored by 1760 aircraft or 4.7 percent increase over the previous year which amounted to 1.681 aircraft. Even with the number of passengers that there are 211441 passengers or more increased 8.91 percent from last year's 194,147 passengers. (Ardita, n.d.)

According to previous data in 2013 Airport (Airport) Husein Sastranegara, Bandung, West Java has been expanded. Airbus classmates can land here. This will establish Bandung as the gateway of West Java tourism. Because, in addition to the main gateway of West Java, which became the main gateway for tourists from Southeast Asia, Husein Sastranegara Airport itself is in Bandung, namely the Capital of West Java Province. (Sastranegara, n.d.) In order to support it, Angkasa Pura I continue to improve the capacity and facilities of Lombok International Airport. Some projects that are done are the construction of additional terminal and parking booth stand, with a length of runway 2.500 meters and can be maximum landed by Boeing 767 aircraft or similar Airbus 330, in order to accommodate the aircraft with Boeing 747 it is necessary to extend the runway to 3,000 meters. There are a lot of airlines that wants to open route to Lombok, there are Jin Air from Korea. Jin Air opened a direct flight to Lombok on April 2017. Jin Air decided to open a direct flight to Lombok because they see the market opportunity in Lombok, because now Lombok became the famous city in Korea. Korea also will open a direct flight to Lombok with regular flights, not charter flight. This discussion has been 
discussed with the General Manager of Korean Air and the Governor of Nusa Tenggara Barat (NTB). (“Mohammad Faozal. 2017,” n.d.)

Another airline that will open a direct flight to Lombok is Royal Brunei Airlines. The executive general manager of Royal Brunei said that they will open a direct flight to Lombok in near time, but before they open a direct flight to Lombok, they will study about the target market in Lombok, because this study will determine all potential that Lombok International Airport has to support this direct flight, and market studies are things to do before actually opening a new flight route. The reason is, Royal Brunei does not want to like other flights that go to one destination and then in a short time it disappears. Royal Brunei already got the information about Lombok tourism, in their opinion, Lombok has a good potential with halal tourism branding, because Lombok is one of the most Muslim-populated Islands of Indonesia and is entitled 'island of a thousand mosques'. Such status may be one of the reasons behind the plan of Indonesian Government to develop Lombok as an Islamic (halal-friendly) tourist destination in Indonesia. (Sulhaini, Saufi, \& Rusdan, 2017).

Jetstar Airways also planning to reopen a direct flight to Lombok International Airport. At first, Jetstar Airways has opened a direct flight to Lombok, but it's closed because the number of passengers is small, but after Lombok International Airport changed its name, the number of passengers of Australia increasing, and that makes Jetstar Airways decide to reopen a direct flight to Lombok soon.

In this year, numbers of airlines that have a route to Lombok are 9 airlines, 3 international airlines and 6 domestic airlines. Those are Garuda Indonesia, Batik Air, Lion Air, Wings Air, Citilink, Air Born (charter flight), Silk Air, AirAsia, and Korean Air (charter flight). The location of Lombok International Airport that is near Ngurah Rai International Airport makes the airlines should think twice if they want to open a direct flight to Lombok, because tourists will think to go through Bali before going to Lombok, rather than having to fly directly to Lombok. The capacity of Lombok International Airport is also still small, so not many large aircraft 
that can be accommodated at the airport and not many international airlines who opened the route to Lombok.

Besides regular flight, there are also international and domestic airlines that open charter flight to Lombok. Air Charter is the business of renting an entire aircraft or in the other way means chartering as opposed to individual aircraft seats, for example purchasing a ticket through a traditional airline. Some air charter companies offer a large variety of aircraft, such as helicopters and business jets. Charter jet categories include turbo props, light jets, mid-size jets, super mid-size jets, heavy jets, long range jets and VIP airliners.

Airlines that have a charter flight to Lombok are Korean air and Air Born. Korean Air opened charter flight to Lombok since July 2017, it because Korean tourist has a great interest to visit Lombok. The number of tourists visiting South Korea to Indonesia in 2015 increased 338,671 people or up $3 \%$ compared to 2014 as many as 328,122 people. But unfortunately, for the year 2016, the number of South Korean tourists to Indonesia has decreased. Estimated number is only 320,000 people, even this result is still below the set target, which is 400,000 people. But, by 2017 , the number of South Korean tourists is on the rise again, and it makes Korea make charter flight to Lombok. Air Born is also opening a charter flight to Lombok. (“Tourism Minister. Yahya, Arif," n.d.)

Since the airport was opened on 20 October 2011, it already brought many benefits to the area around it. One of the biggest effects of this airport is the rising land prices around the airport, the land prices more increasing because everyone wants to open or establish a resort for the tourists. This changed also impact to the income of Lombok citizens, because as we can see the tourists keep increasing every year, so that the economic level of the population increases, because they open businesses that support tourism in the area, employment is also increasingly widespread, such as the construction of hotels that developed every year, the use of local houses to be guest house, and some people who become the guide. In addition, these changes have a good impact to introduce the culture of Lombok to another 
countries and ethnic groups, and add insight to the surrounding population because of the interaction with various ethnic groups and cultures.

The tourism sector plays a significant role in boosting economic growth in NTB. The economy of NTB province as long as in the second quarter of 2017 grew by 6.00 percent. In terms of production, the highest growth was achieved by the business field of accommodation and drinking accommodation by 9.50 percent. This is triggered by an increase in tourist visits due to several national events such as Rinjani 100 and Tambora Charm Festival, and others. The tourism sector contributed substantially in promoting economic growth. In fact, the visit or the arrival of foreign tourists whose coming to Lombok International Airport become the third national. The number of the hotel in Lombok by 2016 is 153 hotels. From the data of Indonesian Hotel and Restaurant Association (PHRI), The moment of development of Lombok International Airpot (LIA) is very appropriate when NTB tourism began to rise, Lombok itself have a very strategic role in the effort to receive tourist arrivals with excellent service. The situation in Lombok is getting more conducive and even the number of passenger arrivals exceeds the public expectation of tourism. In 2016, when the number of national events to make LIA get a visit of 13 thousand passengers. Moreover, according to PHRI data, that the quality of LIA infrastructure is getting better to be one factor of the number of tourists make a visit to Lombok. (Faisal, n.d.)

The development of Lombok International Airport makes a foreign investor planning to manage the airport. It gives the opportunities to Lombok, because if the airport is managed by the foreign investor, it gives chance to the international airlines to open a new route to Lombok and makes Lombok International Airport become the meeting point. but from all the positive things found in Lombok, there are also some things that will be a threat to Lombok tourism. The number of beaches in Lombok is also a threat, because maybe can happen tsunami, and it can be a disaster for Lombok and its tourism. Mount Rinjani, which is a volcano that is still active in Indonesia can be a threat to Lombok, because it could have erupted 
someday. Threats can also occur from the cultural field. The number of foreign cultures that enter into Lombok, making local wisdom lombok be threatened. Residents of lombok must maintain their local wisdom so as not to get displaced with foreign culture. Because, local wisdom is one thing that can sell lombok and make lombok famous in the eyes of the world

\section{Conclusion}

From the results of research, There is no doubt that the future development of the tourism industry depends on a gradual increase in air services, the airport of Lombok gave a good impact for Lombok itself. One of the things that most experienced an increase is the tourism business, every year tourism Lombok increasingly, the foreign tourists have a high interest to visit Lombok, because the location of geographical Lombok very good, where each region Lombok have different tourism potential. With the increase of tourists coming, not only tourism is increasing, regional economic income also increases. Also in the aviation sector which is rise positively, many foreign airlines are opening flight routes that directly connect to Lombok. But, besides it, there are also a weaknesses and threats of Lombok tourism. The location of Lombok International Airport that are close to I Gusti Ngurah Rai International Airport become the weaknesess of Lombok. So, based on the research that Lombok International Airport plays an important role to growth tourism, but it will be better to developing and improving services quality of the entire sector, also the modernization and expansion of the airports to adapt to handle increased demand. As a result of these activities there will be more and more air carriers offering services between States concerned.

\section{References}

Ardita, N. G. (n.d.). Total of Passengers. Retrieved from http://www.suarantb.com/news/2017/10/19/247223/Perpanjangan.Land asan.Pacu.LIA.Dinilai.Belum.Mendesak

Dinas Kebudayaan \& Pariwisata NTB. (n.d.). Retrieved from http://www.disbudpar.ntbprov.go.id/angka-kunjungan-wisatawan-kentb/ 
Faisal, A. H. (n.d.). Perhimpunan Hotel dan Restoran Indonesia (PHRI). 2017. Retrieved from http://nasional.republika.co.id/berita/nasional/daerah/17/07/05/oslwf12 84-kunci-kemajuan-pariwisata-lombok

Lombok Demography. MarlionLLC. 2017. (n.d.). Retrieved from http://marlionllc.com/lombok-ntb-demography-2014-census/

Martono, K., \& Marina, S. (n.d.). Domestic Air Transport Regulations in Indonesia, 3(1), 1-19.

Mohammad Faozal. 2017. (n.d.). Retrieved from http://www.thejakartapost.com/news/2017/07/03/korean-air-charteredplanes-to-start-flying-to-lombok-in-july.html

Rafi, S., \& Rifni, M. (n.d.). Soft Systems Methodology Pada Pengembangan Bandar Udara Provinsi Sulawesi Barat Soft System MethodologyBased on Development of Airport of West Sulawesi, 4(2), 159-176.

Ricardianto, I. P., Djajaputra, D. G., \& Martono, P. D. (2017). Air Transport and Tourism in Indonesia. IOSR Journal of Applied Chemistry, 10(5), 01-19. https://doi.org/10.9790/5736-1005010119

Sastranegara, B. H. (n.d.). Jasa Pelayanan Bandara Halim Perdana Kusuma dan, 3(1), 1-11.

Simarmata, J., \& Keke, Y. (2017). The Influence of Travel Agent, Infrastructure and Accommodation on Tourist Satisfaction, 28(Ictgtd 2016), 281-283.

Sulhaini, Saufi, A., \& Rusdan. (2017). Developing Halal Tourist Destination: Investigating Lombok's Potentials from Destination Marketing Perspective. In A. Saufi, I. R. Andilolo, N. Othman, \& A. A. Lew (Eds.), Balancing Development and Sustainability in Tourism Destinations: Proceedings of the Tourism Outlook Conference 2015 (pp. 67-78). Singapore: Springer Singapore. https://doi.org/10.1007/978-981-10-1718-6_8

Tourism Minister. Yahya, Arif. (n.d.). Retrieved from https://www.cnnindonesia.com/gaya-hidup/20170601160422-307218736/korean-air-buka-rute-seoul-lombok-juli-mendatang/ 